\title{
Preparation, Characterization, Analytical and Thermodynamic Studies of Complex of Ni(II) with Antipyriyl azo-1-nitrozo-2-naphthol as a Complexing Reagent
}

\author{
MASAR A.AWAD
}

Chemistry Department, Faculty of Science, Muthanna University, Iraq

masara32@yahoo.com

Received 6 March 2015 / Accepted 10 March 2015

\begin{abstract}
A new, simple, sensitive and rapid spectrophotometric method is proposed for the determination of trace amount of nickle(II). The method is based on the formation of a 2:1 complex with 3-(4'- antipyriyl azo) 1- nitroso-2-naphthol (APANN) as a new reagent is developed. The complex has a maximum absorption at $469 \mathrm{~nm}$ and $\varepsilon_{\max }$ of $0.6 \times 10^{5} \mathrm{~L} . \mathrm{mol}^{-1} \mathrm{~cm}^{-1}$. A linear correlation $\left(0.1-1.8 \mu \mathrm{g} . \mathrm{mL}^{-1}\right)$ was found between absorbance at $\lambda_{\max }$ and concentration. The accuracy and reproducibility of the determination method for various known amounts of nickle (II) were tested. The results obtained are both precise (RSD was better than $0.11 \%$ ) and accurate (relative error was better than $0.97 \%$ ). The effect of diverse ions on the determination of nickle(II) to investigate the selectivity of the method were also studied. The stability constant of the product was $0.1 \times 10^{7} \mathrm{~L} . \mathrm{mol}^{-1}$. The proposed method was successfully applied to the analysis of synthetic mixtures and raw milk without any preliminary concentration or separation, The apparent thermodynamic parameters were estimated and the obtained results concluded that. The thermodynamic Parameters like $\Delta \mathrm{G}^{\mathrm{o}}, \Delta \mathrm{H}^{\mathrm{o}}$ and $\Delta \mathrm{S}^{\mathrm{o}}$ have been calculated from the effect of temperature on reaction process, its found from these process is Endothermic and spontaneous.
\end{abstract}

Keywords: Nickle(II) determination, Spectrophotometry, Antipyriyl-azo-1-nitroso-2-naphthol, Thermodynamics analysis

\section{Introduction}

Azo dyes constitute the largest and most versatile class of synthetic dyes used in the textile, pharmaceutical, food and cosmetics industries. These dyes are characterized by the presence of one or more azo bonds $(-\mathrm{N}=\mathrm{N}-)$. These are prepared by azo coupling between a diazonium compound and aniline, phenol or other aromatic compound ${ }^{1}$.

Nickel occurs naturally and abundantly in the Earth's crust. The alloys containing nickel are widely used to make coins, jewelry, and stainless steel. However, this metal can be toxic to humans and animals. In humans, nickel toxicity typically presents itself via allergic reactions. Usually, these reactions occur after prolonged skin contact with nickel alloys. People are also exposed to the metal by eating food, drinking water or breathing air that contains small amounts of nickel. Thus, the determination of quantities of nickel in some matrices, such as 
water, plants, animals, and soils can provide important information for the control of food and water, and environmental monitoring ${ }^{2,3}$. At present, several techniques such as ions chromatography ${ }^{4}$, liquid-liquid extraction with atomic absorption spectrometry ${ }^{5}$, atomic fluorescence spectrometry ${ }^{6}$, X-ray fluorescence spectrometry ${ }^{7,8}$ and inductively coupled plasma atomic emission spectrometry ${ }^{9}$, show good sensitivity but is limited because of expensive instrumentation and high cost for routine analysis. In this study, we wish to report this reagent as a selective reagent in spectrophotometric determination of micro amounts of nickle(II).

\section{Experimental}

The reagent was prepared by coupling 1-nitroso-2-naphthol with diazotate 4-amino antipyrine in alkaline alcoholic solution. A diazonium solution was prepared by taking $1 \mathrm{~g}$ of 4-amino antipyrine in $25 \mathrm{~mL}$ of ethanol and concentrated hydrochloric acid with $5 \mathrm{~mL}$ of distilled water and adding sodium nitrite solution drop wise at $\left(0-5{ }^{\circ} \mathrm{C}\right) .1 .2 \mathrm{~g}$ of 1-nitroso-2naphthol was dissolved in $25 \mathrm{~mL}$ of ethanol and $30 \mathrm{~mL}$ of $4.0 \mathrm{M}$ from sodium hydroxide were added at $\left(0-5{ }^{0} \mathrm{C}\right)$. The mixture was left to stand over night. The precipitate was filtered off and recrystallized from ethanol ${ }^{10}$.

\section{Preparation of Nickle(II) complex}

The complex was prepared by direct reaction between nickel chloride hexahydrate and the appropriate ligand (APANN) in 1:2 mole ratio, using aqueous ethanol as solvent. The formed precipitate was filtered off, washed with warm ethanol, then dried in a vacuum desiccator.

\section{Apparatus}

Spectrophotometric measurement were made with Shimadzu UV - visible - 1700 double beam spectrophotometer using $1.00 \mathrm{~cm}$ glass cells. Vibrational spectra were recorded on Test scan Shimadzu FT-IR 8000 series. Measurements of $\mathrm{pH}$ were made using an Hanna, HI9811-5 pH meter equipped with a glass - saturated calomel combined electrode Melting points of both ligand and complex were obtained with an electrothermal melting point apparatus. Conductivity was measured in DMSO $\left(10^{-3}\right)$ solution with an Alpha digital conductivity model-800. Elemantal analysis (C.H.N) were carried out with a EuroEA Elemental Analyser.

\section{Reagents}

\section{All chemicals used were of analytical grades Nickle(II) stock solution (100 $\left.\mu \mathrm{gmL}^{-1}\right)$}

This solution was prepared by dissolving $0.081 \mathrm{~g}$ of nickel chloride hexahydrate in $200 \mathrm{~mL}$ of distilled water, working standard of $\mathrm{Ni}$ (II) solutions were prepared by simple dilution of the appropriate volume of the standard $\mathrm{Ni}$ (II) solution $\left(100 \mu \mathrm{g} \mathrm{mL}^{-1}\right)$ with distilled water.

\section{3-(4'- Antipyriyl azo)1-Nitroso-2-naphthol ( $1 \mathrm{mM}$ )}

$0.0969 \mathrm{~g}$ of reagent was dissolved in $250 \mathrm{~mL}$ of ethanol.

Foreign ion solutions $\left(10 \mu \mathrm{gmL}^{-1}\right)$

All the solutions were prepared by dissolving an appropriate amount of the compound in distilled water in a volumetric flask.

\section{General procedure}

An aliquot of sample containing 1-20 $\mu \mathrm{g}$ of $\mathrm{Ni}(\mathrm{II})$ was transfer into a series of $10 \mathrm{~mL}$ standard flask. $2 \mathrm{~mL}$ of $1 \mathrm{Mm}$ of APANN was added and $\mathrm{pH}$ was adjusted to 9. The complexes formed were solubilized in water and diluted up to $10 \mathrm{~mL}$ in a standard flask. The absorbance of the resulting solution was measured at the respective absorption maxima against a reagent blank prepared under similar condition. 


\section{Results and Discussion}

Properties of (APANN) and its metal chelate

APANN is a tridentate with coordination of azo group nitrogen, hydroxyl group and carbonyl group; it has the following structure Scheme 1:<smiles>Cc1c(/N=N/c2cc3ccccc3c([N+](=O)[O-])c2O)c(=O)n(-c2ccccc2)n1C</smiles>

Scheme 1. Structure of APANN

Owing to the large conjugated system, the compound showed excellent chelating ability to form inner metal chelates. APANN and its metal chelates can be easily solubilized in an aqueous solution .Elemental analyses were carried out on the resulting compound $(\mathrm{C} \%$ calc. 65.11; found 64.46, H\% calc.4.42; found 4.15, N\% calc.18.08; found 17.99) ${ }^{10}$. (m.p) $201 \mathrm{C}^{0}$.

\section{Spectra}

The result of this work indicated that the reaction of $\mathrm{Ni}$ (II) with APANN at $\mathrm{pH}$ yield highly soluble product which can be utilized as a suitable assay procedure for $\mathrm{Ni}(\mathrm{II})$. This product has a maximum absorption at $469 \mathrm{~nm}$ Figure 1 was adopted in all subsequent experiments.

The effect of various parameters on the absorbance intensity of the formed products were studied and the reaction conditions were optimized. The electronic absorption of APANN and its complex in ethanol have been recorded in the wavelength range $(200-800)$ $\mathrm{nm}$ Figure 1. The electronic absorption of complex showed a red shift for $\left(\pi-\pi^{*}\right)$ electronic transition band. [ $\mathrm{Ni}(\mathrm{L})]$ shows one broad in visible region at $(15000-26000) \mathrm{cm}^{-1}$ refer to $\left({ }^{3} \mathrm{~A}_{2 \mathrm{~g}}(\mathrm{~F}) \rightarrow \mathrm{T}_{2 \mathrm{~g}}(\mathrm{~F})\left[v_{1}\right],{ }^{3} \mathrm{~A}_{2 \mathrm{~g}}(\mathrm{~F}) \rightarrow{ }^{3} \mathrm{~T}_{1 \mathrm{~g}}(\mathrm{~F})\left[v_{2}\right],{ }^{3} \mathrm{~A}_{2 \mathrm{~g}}(\mathrm{~F}) \rightarrow \mathrm{T}_{1 \mathrm{~g}}(\mathrm{P})\left[v_{3}\right]\right)$ that is in accordance with octahedral geometry of Ni metal ion ${ }^{11,12}$.

\section{Effect of $p H$}

The $\mathrm{pH}$ of metal complex solutions was adjusted using dilute solutions $(0.05 \mathrm{M}) \mathrm{NaOH}$ and $(0.05 \mathrm{M}) \mathrm{HCl}$ and the effect on absorbance was studied Figure 2. The absorbance of the complex was maximum and constant in the $\mathrm{pH}$ range given in Table 1.

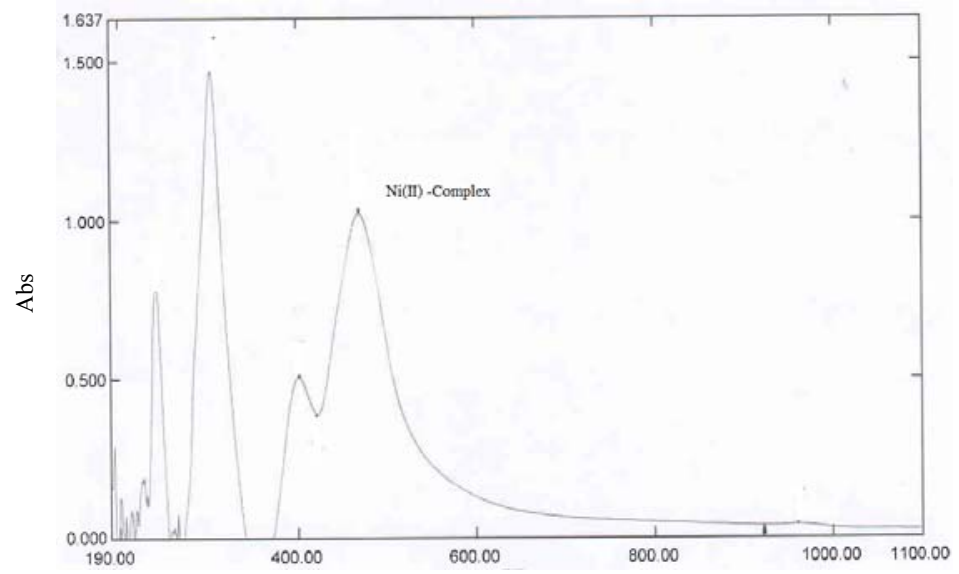

Figure 1. Absorption spectra of $[\mathrm{Ni}(\mathrm{II})+\mathrm{APANN}]$ treated as described under procedure and against a reagent blank 


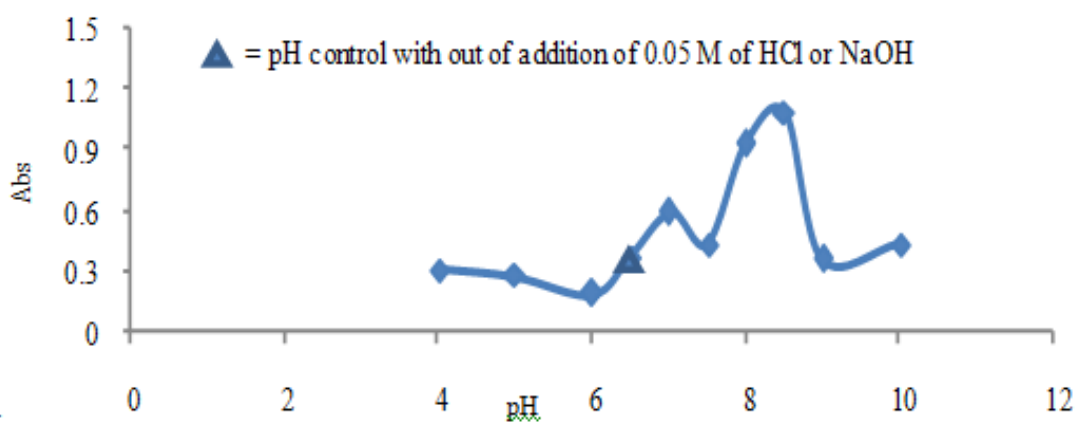

Figure 2. Effect of $\mathrm{pH}$

Table 1. Analytical characteristics of Ni(II) - complex

\begin{tabular}{cc}
\hline Characteristic & $\mathrm{Ni}(\mathrm{II})-$ complex \\
\hline Absorption maximum, $\mathrm{nm}$ & 469 \\
Beer's law range, ppm & $0.1-1.18$ \\
pH range & $8-9$ \\
Sandell's sensitivity, $\mu \mathrm{g} \cdot \mathrm{cm}^{-2}$ & 0.00107 \\
Molar absorptivity, $\mathrm{L} . \mathrm{mol}^{-1} \cdot \mathrm{cm}^{-1}$ & $0.6 \times 10^{5}$ \\
Stability constant, $\mathrm{K}_{\mathrm{st}}\left(\mathrm{L} \cdot \mathrm{mol}^{-1}\right.$ & $0.1 \times 10^{7}$ \\
Melting point for reagent & $199-201 \mathrm{C}^{0}$ \\
Melting point for Ni(II) - complex & $256-258 \mathrm{C}^{0}$ \\
\hline
\end{tabular}

\section{Effect of (APANN) concentration}

When various concentrations of of 3 -(4'- antipyriyl azo) 1-nitroso-2-naphthol was added to afixed concentration of $\mathrm{Ni}(\mathrm{II}), 2.5 \mathrm{~mL}$ of $1 \mathrm{mM}$ (APANN) solution was sufficient to develop the colour to its full intensity and gave minimum blank value, above $2.5 \mathrm{~mL}$, theabsorbance of the blank value was increased causing a decrease in the absorbance of the sample. Therefore, $2.5 \mathrm{~mL}$ of $1 \mathrm{mM}$ of 3-(4'- antipyriyl azo) 1-nitroso-2-naphthol was used in all subsequent experiments (Figure 3 ).

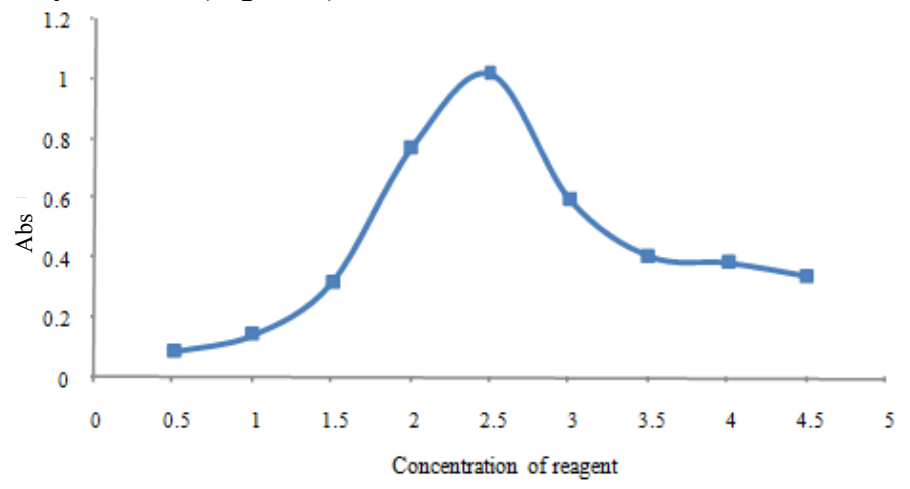

Figure 3. Effect of (APANN) concentration

\section{Effect of reaction time}

The colour intensity reached a maximum after the $\mathrm{Ni}(\mathrm{II})$ has been reached immediately with APANN and became stable after one minute, therefore one minute development time was selected as optimum in the general procedure. The colour obtained was stable for a least 24 hours (Figure 4). 


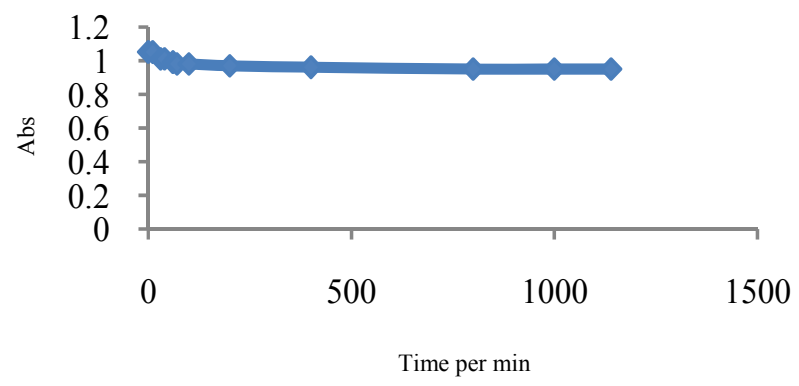

\section{Effect of temperature}

Figure 4. Effect of time on complex of $\mathrm{Ni}[\mathrm{APANN}]_{2}$

The effect of temperature on the colour intensity of the product was studied. In practice, the same absorbance was obtained when the colour was developed at room temperature (15-35) $\mathrm{C}^{\circ}$, but when the volumetric flask were placed in a water - bath at (40-70) $\mathrm{C}^{\circ}$ a loss in colour intensity and stability were observed, therefore it is recommended that the colour reaction should be carried out at room temperature for complex Figure 5 .

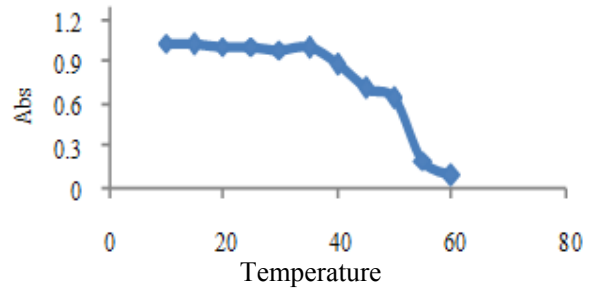

Figure 5. Effect of temperatures on complex $\mathrm{Ni}[\mathrm{APANN}]_{2}$

\section{Calibration graph}

The calibration equation for $\left(0.1-1.8 \mu \mathrm{g} \mathrm{mL}^{-1}\right) \mathrm{Ni}(\mathrm{II})$ is: $\mathrm{Y}=0.9627 \mathrm{X}+0.023\left(\mathrm{R}^{2}=0.9912\right)$.

Since the coloured complex is stable for $24 \mathrm{~h}$, the method can be applied to large series of samples. The molar absorptivity and sandell' sensitivity are given in Table 1.

\section{Composition of the complex}

The composition of complex was studied in the excess of reagent solution by the mole-ratio and Job s methods Figure 6,7. A break at a 1:2 (M:L) mole ratio suggested the formation of complex where $\mathrm{M}=\mathrm{Ni}(\mathrm{II})$ and $\mathrm{L}=\mathrm{APANN}$ under the given condition.

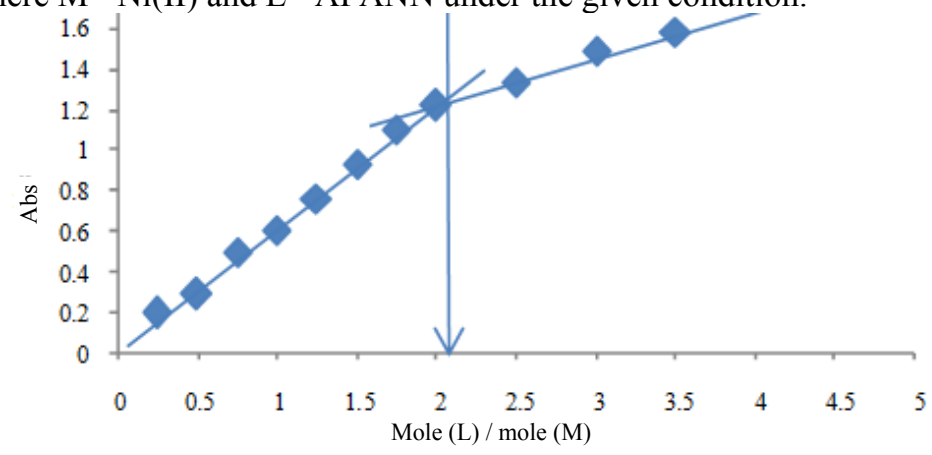

Figure 6. Mole-ratio method for $\mathrm{Ni}[\mathrm{APANN}]_{2}$ complex 


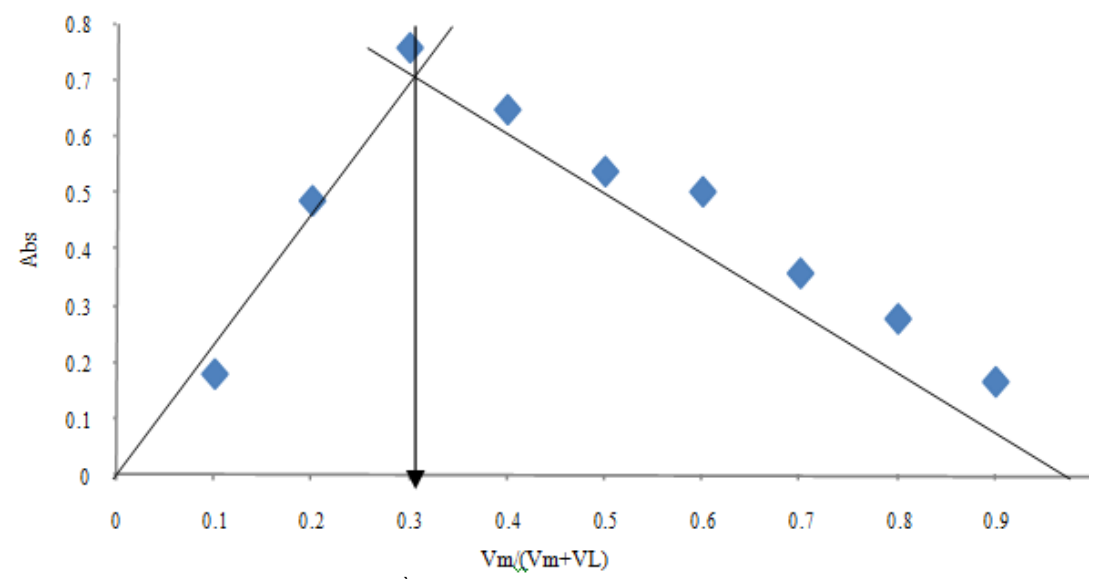

Figure 7. Job s method for Ni[APANN $]_{2}$ complex

\section{Thermodynamics analysis}

The thermodynamic functions, $\Delta \mathrm{H}^{\circ}, \Delta \mathrm{G}^{\mathrm{o}}$ and $\Delta \mathrm{S}^{\mathrm{o}}$ can be estimated using equilibrium constant charging with temperature. The free energy change of the reaction is given by the following equation ${ }^{13,14}$.

$$
\begin{aligned}
\Delta \mathrm{G}^{\mathrm{o}} & =-\mathrm{R} \mathrm{T} \ln \mathrm{k}_{\mathrm{st}} \\
\mathrm{Lnk}_{\mathrm{st}} & =\mathrm{A}-\Delta \mathrm{H} / \mathrm{RT} \\
\Delta \mathrm{G}^{\mathrm{o}} & =\Delta \mathrm{H}^{\mathrm{o}}-\mathrm{T} \Delta \mathrm{S}^{\mathrm{o}}
\end{aligned}
$$

Where $\mathrm{K}_{\mathrm{st}}$ is the The equilibrium constant for various complexes solution at different temperature. The equation (2) was used to calculate the $\Delta \mathrm{H}^{\mathrm{o}}$, by plotting against $1 / \mathrm{T}$. Table (2) and Figure (8) showed a linear relationship and the slope represent $\left(-\Delta \mathrm{H}^{\circ} / \mathrm{R}\right)$ where $\mathrm{R}$ is the gas constant $\left(8.314 \mathrm{JK}^{-1}\right.$. mole $\left.{ }^{-1}\right)$ and $\Delta \mathrm{H}^{\circ}$ ads were calculated. The $\Delta \mathrm{G}^{\mathrm{o}}, \Delta \mathrm{S}^{\mathrm{o}}$ and $\Delta \mathrm{H}^{\mathrm{o}}$ values at different temperature were given in Table 3.

Table 2. The values of the reciprocal of temperature and $\operatorname{lnk}_{\mathrm{st}}$

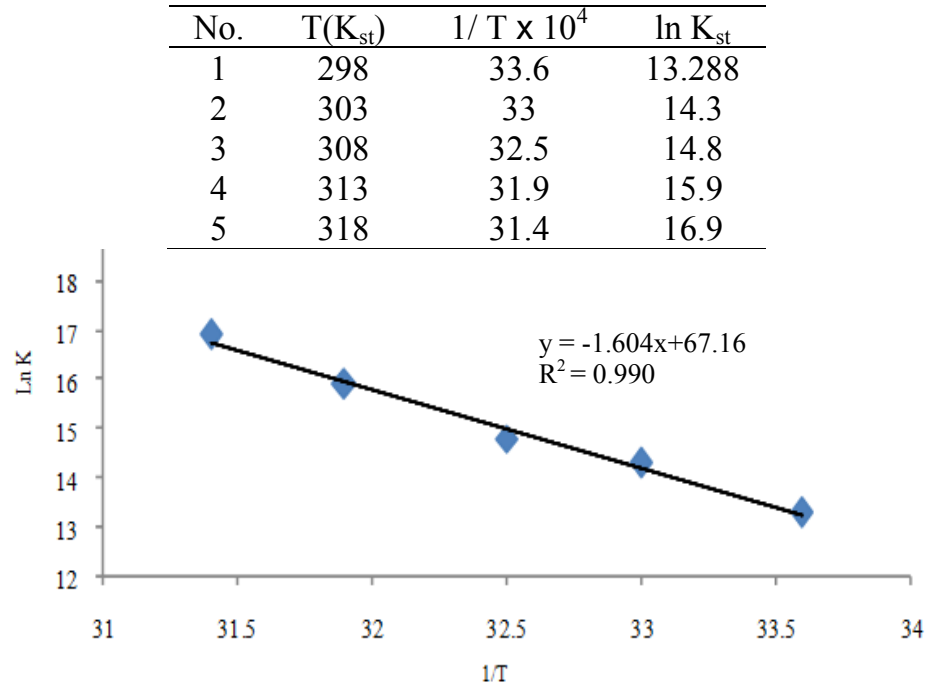

Figure 8. Plot of $\left(\ln \mathrm{k}_{\mathrm{st}}\right)$ against $\left(1 / \mathrm{Tx} 10^{4}\right)$ the reciprocal of temperature 
Table 3. Show the thermodynamic functions of the reaction process

\begin{tabular}{ccccc}
\hline No. & $\mathrm{T}, \mathrm{K}$ & $\Delta \mathrm{H}^{\mathrm{o}} \mathrm{K} \mathrm{J} . \mathrm{mole}^{-1}$ & $\Delta \mathrm{G}^{\mathrm{o}} \mathrm{x} 10^{-3} \mathrm{~K} \mathrm{~J} . \mathrm{mole}^{-1}$ & $\Delta \mathrm{S}^{\mathrm{o}} \mathrm{J} . \mathrm{mole}^{-1} \cdot \mathrm{K}^{-1}$ \\
\hline 1 & 298 & & -32.9219 & +110.5209 \\
2 & 303 & & -36.0237 & +118.9341 \\
3 & 308 & +13.342 & -37.8985 & +123.0904 \\
4 & 313 & & -41.3763 & +132.2353 \\
5 & 318 & & -44.6811 & +140.5486 \\
\hline
\end{tabular}

As seen in Table 3, the negative values of $\Delta \mathrm{G}^{0}$ confirm the feasibility of the process and the spontaneous nature of process, The positive values of $\Delta \mathrm{H}^{\circ}$ indicate the endothermic nature of the process while the positive $\Delta \mathrm{S}^{0}$ corresponds to increase disorder of the system increase.

\section{Conductivity measurements}

The solubility of the complex in dimethyl sulfoxide and ethanol permitted of the molar conductivity of $10^{-3} \mathrm{M}$ solution at $25{ }^{\circ} \mathrm{C}$ and by comparison, the electrolytic nature forcomplex. The low values of the molar conductance data listed in (Table 4) indicate that the complex is non electrolyte ${ }^{15}$.

Table 4. Conductivity values of complex

\begin{tabular}{|c|c|c|}
\hline Complex & $\begin{array}{l}\text { Molar conductivity, } \\
\text { S. mole }{ }^{-1} \mathrm{~cm}^{2} \text { DMSO }\end{array}$ & $\begin{array}{c}\text { Molar conductivity, } \\
\mathrm{S} \text { mole }^{-1} . \mathrm{cm}^{2} \text { Ethanol }\end{array}$ \\
\hline $\mathrm{Ni}$ (APANN) & 11.3 & 15.7 \\
\hline
\end{tabular}

\section{FT-IR of reagent and its complex}

The FT.IR of the free ligand and its metal chelate were carried out in the (400-4000) $\mathrm{cm}^{-1}$ Range. The IR bands of the (APANN) and its Ni(II) complex with their probable assignment are given in Table 4. The IR spectrum of ligand shows a broad band at $3425 \mathrm{~cm}^{-1}$, which can be attributed to the naphtholic $\mathrm{OH}$ group. However, the $v(\mathrm{~N}=\mathrm{N})$ stretching band in the free ligand is observed ${ }^{10}$ at $1535 \mathrm{~cm}^{-1}$. This band is shifted to lower with low intensity at $1492 \mathrm{~cm}^{-1}$ frequency value upon complexation suggesting chelation via the $(M-N)^{16}$. The IR spectrum of the ligand revealed a sharp band at $1650 \mathrm{~cm}^{-1}$ due to $v(\mathrm{C}=\mathrm{O})$ of pyrazole azo ${ }^{10}$. This band is shifted to higher with low intensity at $1676 \mathrm{~cm}^{-1}$ frequency value upon complexation ${ }^{17}$. The bonding of oxygen to the metal ion is provided by the occurrence of band at $455 \mathrm{~cm}^{-1}$ as the result of $v(\mathrm{M}-\mathrm{O})^{18,19}$.

Table 5. Selected FT-IR data of (APAP) and it's complex with Ni(II)

\begin{tabular}{ccccccccc}
\hline Compound & $v(\mathrm{OH})$ & $v(\mathrm{C}=\mathrm{N})$ & $\begin{array}{c}v(\mathrm{C}-\mathrm{H}) \\
\text { arom. }\end{array}$ & $v(\mathrm{~N}=\mathrm{N})$ & $v(\mathrm{C}=\mathrm{C})$ & $v(\mathrm{C}=\mathrm{O})$ & $v(\mathrm{M}-\mathrm{O})$ & $v(\mathrm{M}-\mathrm{N})$ \\
\hline $\mathrm{HL}$ & $3425 \mathrm{~m}$ & $1697 \mathrm{~s}$ & $3062 \mathrm{~m}$ & $1535 \mathrm{~m}$ & $1627 \mathrm{~s}$ & $1650 \mathrm{~s}$ & & \\
{$[\mathrm{I}(\mathrm{L})]$} & $3411 \mathrm{~m}$ & - & $3062 \mathrm{~m}$ & $1492 \mathrm{~m}$ & $1669 \mathrm{~s}$ & $1676 \mathrm{~s}$ & $455 \mathrm{w}$ & $41 \overline{\mathrm{w}}$ \\
\hline \multicolumn{8}{c}{ S: sharp; m: medium; w: weak }
\end{tabular}

On the basis of the FT.IR, stoichiometric and elemental analysis molar conductivity data the structure of complex can be suggested as in Scheme 3.

\section{Applications}

\section{Determination of Nickle(II) in practical samples}

To determine the accuracy and precision of the method, Nickle(II) was determined at two different concentrations. The results are shown in Table 6 indicate that satisfactory precision and accuracy could be attained with proposed method. 
Table 6. Determination of Ni(II) in synthetic samples

\begin{tabular}{|c|c|c|}
\hline Amount taken of Ni(II) p.p.m & Recovery\% & RSD $\%$ \\
\hline 1 & 99.03 & 0.11 \\
\hline 0.5 & 99.81 & 0.22 \\
\hline
\end{tabular}

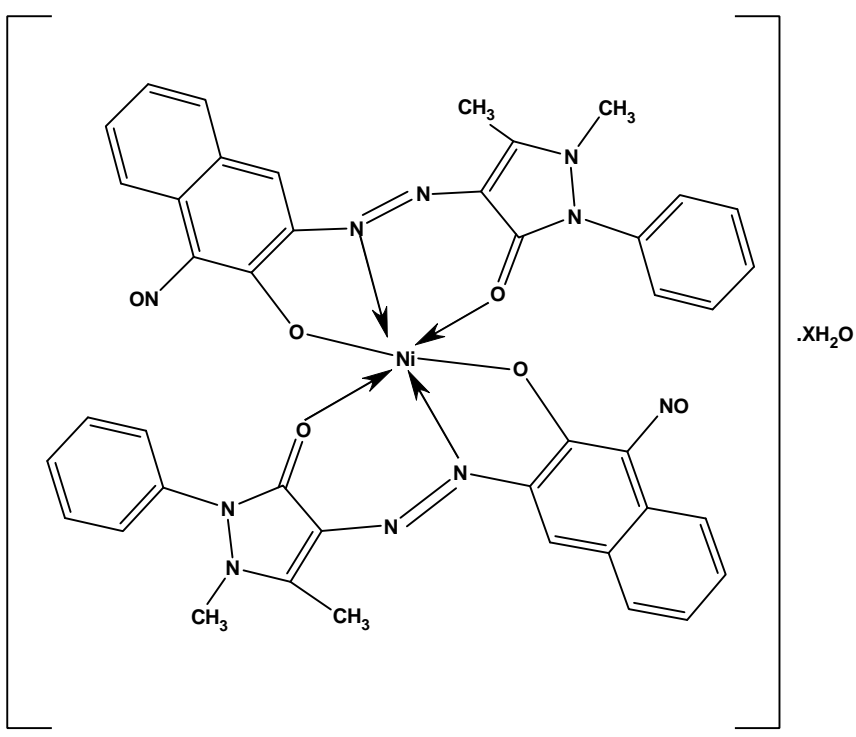

[Ni(APAN) $\left.)_{2}\right] \cdot \mathrm{XH}_{2} \mathrm{O}$

Scheme 2. The suggested structural formula of Ni(II) -complex

\section{References}

1. E. Franciscon, F. Piubeli , F. Fantinatti - Garboggini, C. R. de Menezes, I. S. Silva, A. Cavaco-Paulo and M. J. Grossman, L. R. Durrant., Enzyme and Microbial Technolog., 2010, 46,360-365.

2. Mckenzie H A and Smythe L E, Quantitative Trace Analysis of Biological Materials, Elsevier, Amsterdam, 1988.

3. Khani R and Shemirani F, Determination of Trace Levels of Nickel and Manganese in Soil, Vegetable and Water, Clean - Soil Air Water, 2010, 38(12), 1177-1183.

4. Bidabadi M S, Dadfarnia S and Shabani A M H, J Hazard Mater., 2009, 166(1), 291296; DOI:10.1016/j.jhazmat.2008.11.052

5. Carlosena A, Gallego M and Valcarcel M, J Anal Atom Spectrom., 1997, 12, 479-486; DOI:10.1039/A607939C

6. Simmons W J, Anal Chem., 1973, 45, 1947-1949.

7. San Andres M P, Marina M L and Vera S, Talanta, 1994, 41(2), 179-185; DOI:10.1016/0039-9140(94)80105-3

8. Shar G A and Soomro G A, The Nucleus, 2004, 41, 77-82.

9. Caprioli R and Torcini S, J ChromatogrA, 1993, 640(1-2), 365-369; DOI:10.1016/0021-9673(93)80204-L

10. Shaimaa H Mallah and Hussain J Mohammed, Int J Engg Technol., 2014, 14(2), 102-111. 
11. Greenword N N and Earnshaw A, "Chemistry of the Elements" $2^{\text {nd }}$ Edition, Butterworth Heinemann, 1997.

12. Sheelam C D, Anitha C, Tharmaraj P and Kodimunthiri D, J Coord Chem., 2010, 63, 884-893. DOI: $10.1080 / 00958971003660416$

13. Azzouz A S P, Z Phys Chem., 2002, 216, 1053.

14. Azzouz A S P and AL- Niemi M M H, Z Phys Chem., 2005, 219,1591.

15. Galesic N and Siroki M, Acta Cryst., 1979, 35B, 2931-2937.

16. $\mathrm{Li} \mathrm{X}, \mathrm{Wu} \mathrm{Y,} \mathrm{Gu} \mathrm{D} \mathrm{and} \mathrm{Gan} \mathrm{F,} \mathrm{Dyes} \mathrm{and} \mathrm{Pigments,} \mathrm{2010,} \mathrm{86(2),} \mathrm{182-189;}$ DOI:10.1016/j.dyepig.2010.01.002

17. Pandey G and Narng K K, Synt Reas Inorg Metrog Chem., 2004, 34, 291.

18. Zaki Z M, Spectrochim Acta, 2000, 56(10), 1917-1923; DOI:10.1016/S13861425(00)00249-3

19. Boryana D, Karima B, Elisaventa I and Freddy A, Canadian J Anal Sci., 2004, 49(6), 346-352. 